\title{
Aplikasi Terapi Relaksasi Nafas Dalam terhadap Pengontrolan Marah dengan Pasien Gangguan Jiwa Resiko Perilaku Kekerasan di Wilayah Desa Maleber Kabupaten Cianjur
}

\author{
Biyan Tazqiyatus Sudia ${ }^{1 *}$, Hadi Abdillah S.Kep., Ners., MMRS, Ernawati Hamidah, M.Kep \\ ${ }^{1}$ Universitas Muhammadiyah Sukabumi \\ ${ }^{2}$ Universitas Muhammadiyah Sukabumi \\ ${ }^{3}$ Universitas Muhammadiyah Sukabumi \\ E-mail: 1biyanats@gmail.com, ${ }^{2}$ hadiabdillah91@ummi.ac.id ${ }^{3}$ ernawatihamidah@ummi.ac.id
}

\begin{abstract}
Abstrak
Perilaku kekerasan adalah suatu keadaan dimana seseorang melakukan tindakan yang membahayakan secara fisik baik kepada diri sendiri maupun orang lain, sering juga disebut amuk dimana seseorang dimana marah terhadap suatu stressor dengan Gerakan motorik yang tidak terkontrol. Intervensi keperawatan yang diberikan yakni teknik relaksasi nafas dalam terhadap pengontrolan marah. Tujuan aplikasi ini adalah untuk mengetahui pengaruh aplikasi terapi relaksasi nafas dalam pada pasien dengan masalah risiko perilaku kekerasan di Desa Maleber Kabupaten Cianjur. Metode yang digunakan adalah total sampling, sampel yang diambil sebanyak 1 orang responden yaitu pasien dengan risiko perilaku kekerasan. Data ini diambl dengan menggunakan metode wawancara, observasi, studi dokumentasi dan mengajarkan terapi relaksasi nafas dalam yang dilakukan selama 3x pertemuan dalam 3 hari efektif. Setelah dilakukan tindakan selama 3 hari marah pada pasien risiko perilaku kekerasan, marah dapat dikontrol.
\end{abstract}

Kata Kunci: Relaksasi Nafas dalam, Mengontrol Marah, Gangguan Jiwa, Risiko Perilaku Kekerasan

\begin{abstract}
Violent behaviour is a condition in which a person performs actions that are physically harmful to themselves and others. Often also called tantrums where someone where someone is angry responds to a stressor with uncontrolled motor movements. The nursing intervention given is the deep breathing relaxation technique for controlling anger. The purpose of this application is to determine the effect of the application of deep breathing relaxation therapy in patients with risk problems for violent behavior in Maleber village, Cianjur district. The method used is total sampling, the sample taken is 1 respondent, namely patients at risk of violent behaviour. The data of this study were taken using interviews, observations, documentation studies of deep breathing relaxation therapy carried out for 3 times in 3 days effectively to control ongoing anger in patients at risk of violent behavior after taking action for 3 days of anger in patients at risk of violent behavior, Anger can be controlled
\end{abstract}

Keywords: Deep Breath Relaxation, Controlling Anger, Mental disorders, Risk of Violent Behavior

\section{Pendahuluan}

Gangguan jiwa menurut pedoman penggolongan dan diagnosis gangguan jiwa (PPDGJ) adalah sindrom pola perilaku seseorang yang secara khas berkaitan dengan suatu gejala 
penderitaan (distress) di dalam satu atau lebih fungsi yang penting dari manusia,yaitu fungsi psikologik, perilaku, biologik, dan gangguan itu hanya terletak di dalam hubungan antara orang itu tetapi juga dengan masyarakat (Kelliat \& Akemat 2016).

Orang dengan gangguan jiwa tidak hanya mengalami dampak dan akibat gejala dan penyakit tetapi juga stigmasi, kekerasan merupakan salah satu konsekuensi serius dari gangguan jiwa dan gangguan jiwa yang umum terjadi adalah perilaku kekerasan , menurut Benkowitz, merupakan respon terhadap stressor yang tidak dapat di kontrol ataupun dikendalikan yang dihadapi oleh seseorang yang ditunjukan dengan perilaku aktual melakukan kekerasan baik pada diri sendiri, orang lain, maupun lingkungan entah secara verbal maupun nonverbal yang bertujuan untuk melakukan tindakan melukai orang lain entah secara fisik maupun psikologis (Sutejo, 2011).

Masalah yang mungkin muncul adalah perilaku kekerasan yaitu suatu keadaan dimana seseorang melakukan tindakan yang membahayakan secara fisik baik kepada diri sendiri maupun org lain sering juga disebut amuk dimana seseorang dimana seseorang marah berespon terhadap suatu stressor dengan Gerakan motorik yang tidak terkontrol (Yosep, 2011). Penyebab perilaku kekerasan adalah kemarahan yang dimanifestasikan dalam bentuk fisik.kemarahan tersebut merupakan suatu bentuk komunikasi dan proses penyimpangan pesan dari individu. Orang yang mengalami kemarahan Sebenarnya ia ingin menyampikan pesan, bahwa ia tidak setuju, tersinggung, merasa tidak di anggap, dan merasa tidak di turuti atau diremehkan.

Beberapa macam upaya dalam penanganan pasien dengan gangguan jiwa yang merupakan asuhan keperawatan jiwa spesialis, namun tetap dilakukan secara holistik pada saat melakukan asuhan keperawatan pada klien,berbagai macam terapi pada keperawatan yang dikembangkan dan di fokuskan kepada klien secara individu, kelompok, keluarga maupun kognisi, contohnya ada terapi musik, terapi relaksasi nafas dalam dan terapi psikoreligi yang berhubungan dengan agama (Videbeck, 2011).

Perilaku kekerasan salah satunya bisa ditangani dengan cara teknik relaksasi nafas dalam, yang mana teknik relaksasi nafas dalam dapat mengatur emosi dan menjaga keseimbangan emosi, sehingga emosi marah tidak berlebihan. Relaksasi nafas dalam dipercaya dapat menurunkan ketegangan dan dapat memberikan ketenangan. Relaksasi nafas dalam merangsang tubuh untuk melepaskan opiod endogen (Zelianti, 2011).

Penulis tertarik memilih aplikasi teknik relaksasi nafas dalam karena teknik relaksasi nafas dalam adalah teknik yang paling mudah dilakukan dan dapat dilakukan kapanpun serta dimanapun. Teknik relaksasi juga merupakan Teknik yang sangat simpel dan mudah dipahami oleh siapapun sehingga teknik ini memudahkan penulis maupun klien untuk 
mengaplikasikan teknik relaksasi nafas dalam. Penulis memilih tempat di Desa Maleber Kabupaten Cianjur dikarenakan penulis menemukan dan mendengar informasi terkait kasus seorang warga yang memiliki gangguan jiwa dengan perilaku kekerasan. Berdasarkan latar belakang masalah di atas penulis tertarik untuk melakukan melakukan studi kasus tentang "Aplikasi teknik relaksasi nafas dalam pada pasien gangguan jiwa dengan perilaku kekerasan".

\section{Metode Penelitian}

Metode yang digunakan oleh penulis dalam studi kasus ini adalah penelaahan kasus. Teknik pengambilan sampel yang dilakukan dalam studi kasus ini adalah total sampling yakni suatu teknik penetapan sampel dengan cara memilih sampel secara keseluruhan. Sampel yang diambil dalam studi kasus ini adalah satu orang dengan gangguan jiwa risiko perilaku kekerasan di Wilayah Desa Maleber Kabupaten Cianjur. Lama kegiatan ini 2 bulan, sedangkan lamanya tindakan relaksasi nafas dalam dilakukan sebanyak 3 kali kunjungan dengan waktu sekitar 10 menit dengan frekuensi 3 kali. Pengumpulan data dilakukan melalui observasi, melakukan wawancara langsung kepada klien, dan dokumentasi.

\section{Hasil}

Hasil aplikasi ini menunjukkan bahwa ada pengaruh teknik relaksasi nafas dalam terhadap pengontrolan marah pada orang gangguan jiwa dengan risiko perilaku kekerasan yang dilakukan selama 3 kali kunjungan.

\section{Pembahasan}

Pada tahap pengkajian, penulis memulai pengumpulan data dengan menggali faktor presipitasi yang merupakan faktor pencetus terjadinya gangguan terjadinya gangguan jiwa pada Tn R yaitu berhentinya terapi pengobatan yang dilakukan di pesantren pengobatan karena pasien kabur dari pesantren pengobatan dan tidak mau kembali ke pesantren pengobatan tersebut dan faktor predisposisi atau faktor pendukungnya klien mempunyai pengalaman di masa lalu ketika di pesantren klien sering dibully dan dijauhi teman temannya kemudian ketika ada orang yang membully atau mengejeknya klien merasa kesal dan ingin membalas dengan cara memukul ataupun mengajak berkelahi terhadap orang yang mengejeknya tersebut, maka dari itu klien tidak mempunyai teman atau orang terdekat untuk bercerita tentang masalah yang dihadapinya.

Faktor tersebut sesuai dengan Standar Diagnosis Keperawatan Indonesia (SDKI, 2017) yang menyebutkan terdapat 2 tanda dan gejala yaitu mayor dan minor pada pasien 
perilaku kekerasan, mayor subjektif : mengancam, mengumpat dengan kata-kata kasar, suara keras, bicara ketus, objektifnya : menyerang orang lain, melukai diri sendiri / orang lain, merusak lingkungan, perilaku agresif / amuk, sedangkan minornya yaitu objektif : mata melotot atau pandangan tajam, tangan mengepal, rahang mengatup, wajah memerah, postur tubuh kaku.

Pada tahap perencanaan dan pelaksanaan penulis lebih memfokuskan untuk mengatasi perilaku kekerasan klien sehingga perumusan rencana tindakan dilakukan untuk mengontrol marah pasien dengan mengaplikasikan teknik relaksasi nafas dalam 3 hari, hal ini didukung oleh klien yang cukup kooperatif.penulis menerapkan intervensi yaitu bina hubungan saling percaya, aplikasikan teknik relaksasi nafas dalam. berikan pujian tehadap klien

Penerapan teknik relaksasi nafas dalam ini sesuai dengan hasil penelitian Kinandika (2014) di bangsal abimanyu RSJ dr. Arif Zainudin Surkarta tentang studi kasus terapi relaksasi nafas dalam untuk mengontrol marah pada pasien perilaku kekerasan yang dilakukan selama 3 hari, penulis pun melakukan intervensi selama 3 hari, Setelah dilakukan terapi relaksasi nafas dalam untuk mengontrol marah selama tiga hari, evaluasi akhir dilakukan pada tanggal 7 Mei 2021 didapatkan hasil bahwa setelah dilakukan tindakan relaksasi nafas dalam tampak klien menjadi lebih rileks, tenang dan klien mulai mampu mengontrol emosinya. Artinya setelah dilakukan intervensi terapi nafas dalam klien mengatakan marahnya sedikit berukurang dan klien tampak lebih rileks dan terapi relaksasi nafas dalam efektif berpengaruh dalam pengontrolan marah pada pasien perilaku kekerasan.

\section{Simpulan}

Adanya pengaruh terhadap tindakan terapi relaksasi nafas dalam pada orang gangguan jiwa dengan resiko perilaku kekerasan. Adanya respon positif yang menunjukkan klien mampu mengikuti terapi relaksasi nafas dalam sesuai program dan hasilnya efektif untuk mengontrol marah pada klien, serta klien mampu mengikuti program terapi ini.

\section{Referensi}

Keliat, B. A \& Akemat. (2016). Keperawatan Jiwa: Terapi Aktivitas Kelompok. EGC

Kementerian Kesehatan Republik Indonesia. (2018). Riset Kesehatan Dasar. Sekretariat Negara

Sutejo. (2017). Keperawatan Jiwa. Pustaka Baru Press. 
Tim Pokja SDKI DPP PPNI. (2017). Standar Diagnosis Keperawatan Indonesia Definisi dan Indikator Diagnostik. Dewan Pengurus PPNI.

Videbeck. 2011. Buku Ajar Keperawatan Jiwa. EGC.

Yosep, I. (2011). Keperawatan Jiwa. Refika Aditama.

Zelianti. (2011). Pengaruh Teknik Relaksasi Nafas Dalam Terhadap Tingkat Emosi Klien Perilaku Kekerasan di Rumah Sakit Jiwa Daerah dr.Amino Gondohutumo. Politeknik Kesehatan

Denpasar. (https://garuda.kemdikbud.go.id/documents/detail/183419) 